\title{
Nutritional value of huitlacoche, maize mushroom caused by Ustilago maydis
}

\author{
Mehmet AYDOĞDU ${ }^{1 *}$, Muharrem GÖLÜKÇÜ ${ }^{1}$
}

\begin{abstract}
Smutty maize cobs, caused by Ustilago maydis ((DC) Corda.), a fungus belonging to Basidiomycetes, can be seen wherever maize is grown. It is considered as a fungal disease limiting maize yield worldwide. However, in Mesoamerica, it is called as "huitlacoche" and evaluated as an edible mushroom. The present study was conducted to examine nutritional characteristics of this mushroom. In the study, smutty cobs naturally infected by $U$. maydis were randomly gleaned from plants in maize producing areas in the Mediterranean region of Turkey, in 2015. Huitlacoche was analyzed in terms of proximate composition, fatty acids, mineral elements, total phenolic and flavonoid matters and antioxidant activity. Average protein content was $12 \%$, while fatty acids ranged from 0.44 to $42.49 \%$ (dry basis). Of the 11 fatty acids, oleic and linoleic acids had the highest percentages. Phosphorus $(342.07 \mathrm{mg} / \mathrm{kg})$ and magnesium $(262.69 \mathrm{mg} / \mathrm{kg})$ were found in high quantities. As for total phenolic and flavonoid matters were $113.11 \mathrm{mg} \mathrm{GAE} / \mathrm{kg}$ and $28.51 \mathrm{mg} \mathrm{CE} / \mathrm{kg}$, respectively. The study suggests that huitlacoche has numerous good nutritional features for human diet, thus, it can be evaluated as a valuable food source in international cuisines.
\end{abstract}

Keywords: edible mushroom; food properties; maize smut fungus.

Practical Application: Promoting huitlacoche as a functional food for human diet.

\section{Introduction}

Approximately 14000 species of fungi are considered as mushrooms. Today about 7000 species possess varying degrees of edibility, of which 100 economically cultivated, approximately 60 commercially cultivated, and about 10 species cultivated on an industrial scale (Chang \& Miles, 2004). Throughout the world, production of mushroom and truffles was nearly 10 million tonnes in total in 2013 (Food and Agriculture Organization of the United Nations, 2015).

Galls (tumours) on maize cobs, induced by U. maydis, are considered smut disease, constraint to yield, in the world. However, they have been gleaned from naturally infected fields and eaten in central parts of Mexico and Latin America since the times of the Aztecs, who named it cuitlacoche (Kennedy, 1989). Huitlacoche or cuitlacoche comes from the word Nahuatl (the language of the Mexicas or Aztecs) "cuitlacochin" or "cuitlacuchtli" that means "degenerate corn on the cob" (Simeón, 1977; Sahagún, 1989; Juárez-Montiel et al., 2011). In Mexico, these smut galls designated as maize mushrooms, Mexican truffles, or maizteca mushrooms are an edible delicacy and an important food source in Mesoamerica (Valverde et al., 1993).

Huitlacoche has been recently introduced into the "nouveau cuisine" of luxury restaurants with notable success (Ruiz-Herrera \& Martínez-Espinoza, 1998). The use of huitlacoche as food has spread to the point that it is currently a culinary delight of international chefs due to the unique mixture of components that produce its flavor, aroma, and organoleptic characteristic (Lizárraga-Guerra et al., 1997). Cuitlacoche is served in soups, appetizers and entrees at many fashionable
Mexican restaurants in major metropolitan areas in the United States. Recipes for cuitlacoche are available on the internet and in gourmet Mexican cookbooks. Fresh or frozen cuitlacoche occasionally is available at farmers' markets or from local suppliers in the United States (Pataky \& Snetselaar, 2006).

About 400 - 500 tons of huitlacoche are sold annually during July and August at markets in Mexico City. It is also processed by at least six companies that sell the specialty mushroom canned or lyophilized. Interest in producing $U$. maydis as a specialty mushroom in the U.S. has increased recently due to an emerging acceptance of huitlacoche by the North American public, who view it as a gourmet food item that is part of a growing market for haute Mexican cuisine. In the United States fresh and frozen huitlacoche has sold for as much as $\$ 20 / \mathrm{kg}$ (Pataky, 1991; Villanueva, 1997; Pataky \& Chandler, 2003).

Although resources, which are related to recipes and marketing of huitlacoche on the internet, are available, its nutritional features have not been well documented yet. Thus, the objective of the present study was to examine nutritional properties of huitlacoche in the Mediterranean region of Turkey.

\section{Materials and methods}

Smutty cobs (galls) of dent maize (Zea mays var. indentata) (cv Side) in the field constituted the main material of the study. The galls were obtained from smutty plants from maize-producing areas of Batı Akdeniz Agricultural Research Institute, located in Aksu district of Antalya Province in the Mediterranean Region of Turkey in 2015. 


\subsection{Observation of the smutty galls}

Field observations were initiated and repeated at 3 days intervals in the silk emergence period (at the beginning of the August in 2015) in a 5 ha- maize producing area in the Aksu location of the Institute. However, immediately after emerging galls on cobs, they were monitored daily and physical changes were noted.

\subsection{Sampling}

A total of 42 galls $(1.2-14.1 \mathrm{~cm}$ dimater in size $)$ on the maize cobs were picked 18 days later (following appearance of the galls on the cobs) for evaluation on August 25th in 2015.

\subsection{Proximate composition}

Moisture content was determined by drying them up to reach constant weight in an oven at $72{ }^{\circ} \mathrm{C}$ (Cemeroğlu, 2007). In order to establish the chemical composition, the dried sample was milled with a laboratory type miller (Retch GM200).

\subsection{Mineral elements}

To evaluate the overall nutritional contents of the huitlacoche, mineral matter compositions were analyzed according to Kaçar $\&$ Inal (2008). For this purpose, microwave digestion method used to prepare sample and then mineral contents $(\mathrm{Na}, \mathrm{Ca}$, $\mathrm{Mg}, \mathrm{P}, \mathrm{Fe}, \mathrm{Zn}$ and $\mathrm{Mn}$ ) of the digested samples were measured using ICP (Varian).

\subsection{Fat content}

Samples were extracted successively with petroleum ether using a soxhlet extractor for $3 \mathrm{~h}$ to determine the total fat content (Association Official Analytical Chemists, 2005). Fat contents were calculated as percentage on dry matter bases (American Oil Chemists' Society, 1990).

\subsection{Fatty acid composition}

The fatty acid compositions were determined by gas chromatography (Agilent 5975C) coupled to flame ionization detector and mass spectrometry (Agilent 5975C) (GC-MS-FID). First, fatty acid methy esters (FAMEs) were prepared (Garces \& Mancha, 1993) and then injected in to GC-MS/FID. Separations were performed using an HP innowax capillary column (60 m, 0.25-mm i.d., $0.25 \mu \mathrm{m}$ film thickness). Helium was used as carrier gas at a flow rate of $0.8 \mathrm{~mL} / \mathrm{min}$. The temperature programming for the column was applied as follow: started from $150^{\circ} \mathrm{C}$ and raised to $230^{\circ} \mathrm{C}$ with an increment of $2^{\circ} \mathrm{C} /$ minute and hold at $230^{\circ} \mathrm{C}$ for 10 minutes. Sample of $1 \mu \mathrm{L}$ was injected by auto sampler with a split mode (1:40). The content (percentage by weight) of fatty acids was calculated from their corresponding integration data. MS spectra were monitored between 35 - $450 \mathrm{amu}$ and the ionization mode used was electronic impact at $70 \mathrm{eV}$. The relative percentage of the components was calculated from GC-FID peak areas. FAMEs were identified by comparison of their retention times with those of the reference standards. FAMEs were further identified by using WILEY and NIST libraries of the GC-MS system.

\subsection{Crude protein content}

Protein contents were determined by Kjeldahl method. 6.25 conversion factor was used to calculate protein content of the samples (Egan et al., 1981).

\subsection{Crude cellulose}

For crude cellulose analysis, $3 \mathrm{~g}$ sample was firstly boiled with sulfuric acid and then with potassium hydroxide, recpectively. Afterward, the sample was filtered through a strainer and washed by acetone. Washed residue was burned by drying. The weight difference appeared as a result of the burning was calculated as the crude cellulose, and it was calculated as percentage (Özkaya, 1998).

\subsection{Total phenolic and flavonoid matter}

Total phenolic matter (TPM) content was determined using the method of Singleton et al. (1999). $1 \mathrm{~g}$ dry sample was extracted with $10 \mathrm{~mL}$ of methanol:water mixture (80:20) for 1 hour at $180 \mathrm{rpm}$ on an orbital shaker. TPM content of this extract was measured at $765 \mathrm{~nm}$ with UV-Vis spectrophotometer. The results were expressed as gallic acid equivalent using standard calibration curve of this phenolic compound. Using the same extract obtained in total phenolic matter analysis according to Zhishen et al. (1999), total flavonoid matter content of the sample was detected with spectrophotometric method and results were given $\mathrm{mg}$ catechin equivalent (CE)/kg dry sample.

\subsection{Antioxidant activity, IC50}

Antioxidant activity (AA) was found with DPPH method (Lafka et al., 2007). Antioxidant capacity of this extract (the same as the total phenolic matter extraction procedure) was measured at $515 \mathrm{~nm}$ by spectrophotometer. Results were calculated as inhibition capacity (IC50).

\section{Results}

The galls (huitlacoche) on maize cobs were observed as semi-fleshy, consisting of the smut fungus intermixed with enlarged cells of the cobs of the plant. The galls were at first firm and whitish in colour and covered with a semiglossy peridium. Size of the galls ranged from $1.2 \mathrm{~cm}$ to $14.1 \mathrm{~cm}$ diameter and they were categorized into three (small, medium and large) group according to their sizes (Table 1). In the ears, the ovaries and glumes were smutted. The galls were odourless. External part of the galls were mostly whitish in colour and lightly soft and delicate structure while internal parts were black due to teliospores of the fungus.

Dry matter of the huitlacoche was $10 \%$. However, carbonhydrate content was $45 \%$ (dry basis) (Table 2 ).

Composition of the huitlacoche ranged from trace (manganese: $1.91 \mathrm{mg} / \mathrm{kg}$ ) to high amount (phosphorus: $342.07 \mathrm{mg} / \mathrm{kg}$ ). 
Table 1. Gall diameter and weight evaluated for physical examination.

\begin{tabular}{ccc}
\hline $\begin{array}{c}\text { Gall (huitlacoche) } \\
\text { size }\end{array}$ & $\begin{array}{c}\text { Gall size diameter }(\mathrm{cm}) \\
\text { (from min. to max.) }\end{array}$ & $\begin{array}{c}\text { Gall weight }(\mathrm{g}) \\
\text { (from min. to max.) }\end{array}$ \\
\hline Small & $1.2-5.0$ & $15-83$ \\
Medium & $5.5-8.7$ & $98-168$ \\
Large & $8.9-14.0$ & $185-302$ \\
\hline
\end{tabular}

Table 2. Proximate composition of the huitlacoche samples.

\begin{tabular}{cc}
\hline Content of the huitlacoche & Ratio of the components (\%) \\
\hline Moisture & $90.0 \pm 0.18$ \\
Crude protein & $12.0 \pm 0.1$ \\
Crude cellulose & $11.0 \pm 0.14$ \\
Total fat & $1.80 \pm 0.02$ \\
Carbohydrate & $45.0 \pm 0.26$ \\
\hline
\end{tabular}

All values are means \pm standart deviation of three analyses of the same sample.

Table 3. Amount of some elements of huitlacoche.

\begin{tabular}{cc}
\hline Minerals & Content $(\mathrm{mg} / \mathrm{kg})$ \\
\hline Manganese $(\mathrm{Mn})$ & $1.91 \pm 0.07$ \\
Zinc $(\mathrm{Zn})$ & $2.51 \pm 0.06$ \\
Sodium $(\mathrm{Na})$ & $12.06 \pm 0.08$ \\
Magnesium $(\mathrm{Mg})$ & $262.69 \pm 0.02$ \\
Calcium $(\mathrm{Ca})$ & $18.61 \pm 0.01$ \\
Phosphorus $(\mathrm{P})$ & $342.07 \pm 0.02$ \\
Iron $\pm(\mathrm{Fe})$ & $2.85 \pm 0.08$ \\
\hline
\end{tabular}

All values are means \pm standart deviation of three analyses of the same sample.

Table 4. Fatty acid content of the huitlacoche.

\begin{tabular}{cr}
\hline Fatty acids & Content (\%) \\
\hline Myristic acid & $0.44 \pm 0.01$ \\
Pentadecanoic acid & $0.67 \pm 0.01$ \\
Palmitic acid & $14.79 \pm 0.17$ \\
Palmitoleic acid & $2.10 \pm 0.16$ \\
Margaric acid & $0.51 \pm 0.01$ \\
Stearic acid & $3.94 \pm 0.06$ \\
Oleic acid & $42.49 \pm 0.12$ \\
Linoleic acid & $26.97 \pm 0.18$ \\
Linolenic acid & $0.84 \pm 0.01$ \\
Arachidic acid & $2.86 \pm 0.10$ \\
11-Eicosenoic acid & $4.39 \pm 0.10$ \\
\hline
\end{tabular}

All values are means \pm standart deviation of three analyses of the same sample.

Table 5. Total phenolic and flavonoid matter and antioxidant capacity of the huitlacoche.

\begin{tabular}{lr}
\hline Total phenolic matter & $113.11 \pm 0.2 \mathrm{mg} \mathrm{GAE} / \mathrm{kg}$ dry sample \\
Total flavonoid matter & $28.51 \pm 0.16 \mathrm{mg} \mathrm{CE} / \mathrm{kg}$ dry sample \\
Antioxidant activity, IC50 & $186.44 \pm 0.09 \mathrm{mg} / \mathrm{mg} \mathrm{DPPH}$ \\
\hline All values are means \pm standart deviation of three analyses of the same sample.
\end{tabular}

However, it was rich in magnesium $(262.69 \mathrm{mg} / \mathrm{kg})$. The amount of calcium $(18.61 \mathrm{mg} / \mathrm{kg})$ and sodium $(12.06 \mathrm{mg} / \mathrm{kg})$ were also considerably high (Table 3 ).

Fatty acids content of the huitlacoche varied from $0.44 \%$ (Myristic acid) to $42.49 \%$ (Oleic acid) among 11-fatty-acids. In addition, fatty acids, margaric, pentadecanoic, and linolenic acid, were found trace quantities with $0.51,0.67$, and $0.84 \%$, respectively. As for, palmitic acid was $14.79 \%$. Total fat content was $1.85 \%$ (dry basis) (Table 4 ).

Antioxidant capacity of the huitlacoche was found as $186.44 \mathrm{mg} / \mathrm{mg}$ DPPH while total phenolic matter and flavonoid matter were $113.11 \mathrm{mg} \mathrm{GAE} / \mathrm{kg}$ and $28.51 \mathrm{mg} \mathrm{CE} / \mathrm{kg}$ dry basis, respectively (Table 5).

\section{Discussion}

Huitlacoche is commercially produced in some sweet corn cultivars (Pataky, 1991; Valverde et al., 1993; Toit \& Pataky, 1999a, b). However, it was found that flint and dent corn cultivars were more suitable for huitlacoche yield than the popcorn and sweet corn varieties (Aydoğdu, 2015). Likewise, it was reported that maximum yields of huitlacoche from male-sterile field corn hybrids were about $40 \%$ greater than those from sweet corn hybrids (Pataky \& Chandler, 2003). Pataky (1991) also stated that extremely susceptible genotypes may exist among dent, flint, floury and other types of corn and ear galls from these types of corn may be equally well suited for huitlacoche. Therefore, in the present study, Side (dent corn variety) was evaluated as the huitlacoche source. In our field observations, galls formed as a result of natural infection of $U$. maydis began to appear on the ears of cv. Side from the first week of the August in 2015. The galls were in different size and shape but in similar colour and texture. Maximum weight of the galls varied from 180 to $302 \mathrm{~g}$ among the huitlacoche samples. Valverde et al. (1993) reported that after artificial inoculation of U. maydis into ears of some sweet corn varieties, gall weight of $100 \%$-infected XPH 2688 sh2 ears and Sweetie 82' ears ranged from 230 to $600 \mathrm{~g}$ and from 70 to $350 \mathrm{~g}$, respectively, during the 8-day sampling period. The authors also expressed that optimal huitlacoche harvest time varied among hybrids from 17 to 19 days after inoculation. As for, Pataky \& Chandler (2003) reported that depending on inoculation and harvest time, ear weight varied between $229 \mathrm{~g}$ and $388 \mathrm{~g}$. The authors also underscored that yield and quality of huitlacoche were optimal during a 1- to 2-days harvest window about 16 days after inoculation and quality of huitlacoche harvested 16 or 17 days after inoculation was acceptable. Taking into consideration of these traits and after observing the ear galls of cv. Side, 18 days later, ear galls were harvested and weighed and then sampled to assess yield and proximate composition.

Mushrooms contain a high moisture percentage that ranges between 80 and $95 \mathrm{~g} / 100 \mathrm{~g}$, approximately (Valverde et al., 2015). Dry matter of mushroom species is low: commonly about $100 \mathrm{~g} \mathrm{~kg}^{-1}$ (Kalač, 2013). Likewise, in our study, moisture percentage of the huitlacoche samples was $90 \%$. Accordingly, dry matter of the samples were low (10\%). In terms of these traits, huitlacoche is similar to other edible mushrooms.

Huitlacoche has a considerable amount of crude protein (9.8\% average in creole maizes, and $11.3 \%$ in hybrid maize) (ValdezMorales et al., 2010). In addition, the protein content of huitlacoche varied from 10.0 to $14.5 \%$ (dry basis) (Vanegas et al., 1995). However, Valverde \& Paredes-López (1993) reported that protein content ranged from 11.5 to $16.4 \%$. It is similar or sometimes superior to other edible mushrooms and definitely superior to the maize protein content (10\%) (Valverde et al., 2015). In the 
present study, average protein content of the samples was $12 \%$ (dry basis). Our findings were coherent with the earlier reports. In this regard, being rich in protein, huitlacoche could be suggested as an alternative protein source for vegetarian diets.

Free amino acids are crucial nonvolatile compounds involved in the overall taste of many food products. Lysine ( $3.21 \mathrm{mg} / \mathrm{g}$ dry weight) was the most abundant amino acid followed by glycine, valine, leucine, and glutamic acid in huitlacoche. Besides 14 common amino acids, $\gamma$-aminobutyric acid, ornithine, and tricholomic acid were also found. The concentrations of all amino acids were in the range of $0.08 \mathrm{mg} / \mathrm{g}-3.21 \mathrm{mg} / \mathrm{g}$ (Lizárraga-Guerra \& López, 1996). Huitlacoche contains almost all essential amino acids, lysine (6.3 - $7.3 \mathrm{~g} / 100 \mathrm{~g}$ protein) being one of the most abundant. Other abundant amino acids include serine, glycine, aspartic and glutamic acid, which collectively account for 44.3 to $48.9 \%$ of total amino acids (Valverde et al., 2015). Huitlacoche contains 18 amino acids, of these, essential amino acids accounted for $37.8 \%$ of the total. Lysine was $27.2 \%$ of the essential amino acids (Martínez-Flores et al., 2008).

Twenty-seven carbohydrates were detected in huitlacoche; however, only 16 were completely identified. The most abundant monosaccharides, glucose (143.2 mg/g) and fructose $(71.10 \mathrm{mg} / \mathrm{g})$ were, followed by glycerol $(8.5 \mathrm{mg} / \mathrm{g})$, sorbitol $(4.45 \mathrm{mg} / \mathrm{g})$, and mannitol (3.17 mg/g) (Lizárraga-Guerra \& López, 1998). In the present study, crude carbohydrate constituted $45 \%$ of the total dry matter of the samples. Valdez-Morales et al. (2010) identified eight monosaccharides and eight alditols in huitlacoche. Glucose and fructose were the most abundant and constituted approximately $81 \%$ of the total carbohydrates. Additionly, considerable amount (11\% of the total dry matter) of crude cellulose was detected from the huitlacoche in our study. Containing such amounts of the cellulose, huitlacoche can be beneficial to the digestive system. Besides, the samples contained very low crude fat (1.8\%) (dry basis). However, Vanegas et al. (1995) reported that fat content of huitlacoche ranged from 2.7 to $6.5 \%$ (dry basis). Low fat content of huitlacoche means that it has low-calorie and accordingly it is useful for low-calorie diet of human.

Valverde \& Paredes-López (1993) reported that most fatty acids were represented by the linoleic and linolenic acids (72.1 to $73.6 \%$ of the total) in huitlacoche. Vanegas et al. (1995) stated huitlacoche showed high contents of oleic and linoleic acids. In the present study, the huitlacoche contained a number of fatty acids. Of the fatty acids, oleic acid (42.49\%) and linoleic acid (26.29\%) constituted the highest percentages. Besides, palmitic acid formed $14.79 \%$ of the huitlacoche. Valverde et al. (2015) underscored that high content of essential fatty acids suggests an interesting nutritional value for huitlacoche.

Mushrooms contain biologically active polysaccharides that mostly belong to group of beta-glucans. These substances increase host immune defense by activating complement system, enhancing macrophages and natural killer cell function. Beta-glucans also show anticarcinogenic activity (Akramiene et al., 2007). The content of $\beta$-glucans in huitlacoche is similar to other edible mushrooms (Valdez-Morales et al., 2010). Mushrooms provide important nutrients, including selenium, potassium, riboflavin, niacin, vitamin D, proteins, and fiber (Valverde et al., 2015). In our study, phosphorus and magnesium elements were high in the huitlacoche. Calcium and sodium were also a considerable amounts. In addition, quantities of total phenolic and flavonoid matters were found to be quite high. Thus, containing high percentage of these significant elements, phenolic and flavonoid matters makes huitlacohe an important food source as well as other edible mushrooms.

\section{Conclusion}

In recent years, searching and examining foods having nutritional properties as well as specific functions, including improving health or reducing disease risks, have been emerged all around the world. In this context, little is known about huitlacoche and its nutritional value as an edible mushroom in the worldwide, except for Mesoamerica and United States of America. Accordingly, the main purpose of the present study was to determine nutrient compositon of huitlacoche and to raise awareness about this edible mushroom. In addition, in the present study, element content, total phenolic and flavonoid matters and antioxidant activity of the huitlacoche were revealed for the first time. In conclusion, the study suggested that huitlacoche has numerous common nutritional traits as other edible mushrooms and even, it is more superior to them with its bioactive substances. Since huitlacoche has been gaining popularity in international cuisines. Further studies are needed to promote its nutritional value as well as its storage, and trade.

\section{References}

Akramiene, D., Kondrotas, A., Didziapetriene, J., \& Kevelaitis, E. (2007). Effects of beta-glucans on the immune system. Medicina, 43(8), 597-606. PMid:17895634.

American Oil Chemists' Society - AOCS. (1990). Fatty acids in oils and fats (15th ed., vol. 2, pp. 963, Method 969.33). Illinois: AOCS.

Association Official Analytical Chemists - AOAC. (2005). Fat (crude) in nuts and nut products (Method 948.22). Washington: AOAC.

Aydoğdu, M. (2015). Huitlacoche yield in some maize varieties in the Mediterranean region of Turkey. Food Science and Technology, 35(2), 386-390. http://dx.doi.org/10.1590/1678-457X.6673.

Cemeroğlu, B. (2007). Food analyses (Publications of Food Technology Association, no. 34). Ankara: FTA.

Chang, S. T., \& Miles, P. G. (2004). Mushrooms: cultivation, nutritional value, medicinal effect and environmental impact (451 p.). Washington: CRC Press.

Egan, H., Kırk, R. S., \& Sawyer, R. (1981). Perason's chemical analysis of foods (591 p.). New York: Longman Inc.

Food and Agriculture Organization of the United Nations - FAO. (2015). FAOStat: crops. Rome: FAO. Retrieved from http://faostat3. fao.org/browse/Q/QC/E

Garces, R., \& Mancha, M. (1993). One-step lipid extraction and fatty acid methyl esters preparation from fresh plant tissues. Analytical Biochemistry, 211(1), 139-143. PMid:8323025. http://dx.doi. org/10.1006/abio.1993.1244.

Juárez-Montiel, M., León, S. R., Chávez-Camarillo, G., HernándezRodríguez, C., \& Villa-Tanaca, L. (2011). Huitlacoche (corn smut), caused by the phytopathogenic fungus Ustilago maydis, as a functional food. Revista Iberoamericana de Micologia, 28(2), 6973. PMid:21352944. http://dx.doi.org/10.1016/j.riam.2011.01.001. 
Kaçar, B., \& Inal, A. (2008). Plant analyses (Nobel Publication, no. 1241. 912s). Ankara.

Kalač, P. (2013). A review of chemical composition and nutritional value of wild-growing and cultivated mushrooms. Journal of the Science of Food and Agriculture, 93(2), 209-218. PMid:23172575. http://dx.doi.org/10.1002/jsfa.5960.

Kennedy, D. (1989). The art of mexican cooking. New York: Bantam.

Lafka, T. I., Sinanoglou, V., \& Lazos, E. S. (2007). On the extraction and antioxidant activity of phenolic compounds from winery wastes. Food Chemistry, 104(3), 1206-1214. http://dx.doi.org/10.1016/j. foodchem.2007.01.068.

Lizárraga-Guerra, R., \& López, M. G. (1996). Content of free amino acids in Huitlacoche (Ustilago maydis). Journal of Agricultural and Food Chemistry, 44(9), 2556-2559. http://dx.doi.org/10.1021/jf960017u.

Lizárraga-Guerra, R., \& López, M. G. (1998). Monosaccharide and alditol contents of Huitlacoche (Ustilago maydis). Journal of Food Composition and Analysis, 11(4), 333-339. http://dx.doi.org/10.1006/ jfca.1998.0597.

Lizárraga-Guerra, R., Guth, H., \& López, G. M. (1997). Identification of the most potent odorants in huitlacoche (Ustilago maydis) and austern pilzen (Pleurotus sp.) by aroma extradilution analysis and static head-space samples. Journal of Agricultural and Food Chemistry, 45(4), 1329-1332. http://dx.doi.org/10.1021/jf960650f.

Martínez-Flores, A., Corrales-García, J. J., Espinosa-Solares, T., GarcíaGatica, P. G., \& Villanueva-Verduzco, C. (2008). Postharvest changes in the edible mushroom huitlacoche (Ustilago maydis (D.C.) Corda). Revista Chapingo. Serie Horticultura, 14(3), 339-346.

Özkaya, H. (1998). Analytic food quality control (Agriculture Faculty Publications, no. 1086). Ankara: Ankara University.

Pataky, J. K. (1991). Production of cuitlacoche [Ustilago maydis (DS) Corda] on sweet corn. HortScience, 26(11), 1374-1377. Retrieved from http://hortsci.ashspublications.org/content/26/11/1374.full. pdf + html

Pataky, J. K., \& Chandler, M. A. (2003). Production of huitlacoche, Ustilago maydis: timing inoculation and controlling pollination. Mycologia, 95(6), 1261-1270. PMid:21149027. http://dx.doi.org/1 0.1080/15572536.2004.11833034.

Pataky, J. K., \& Snetselaar, K. M. (2006). Common smut of corn. The Plant Health Instructor. http://dx.doi.org/10.1094/PHI-I-2006-0927-01.

Ruiz-Herrera, J., \& Martínez-Espinoza, A. D. (1998). The fungus Ustilago maydis, from the aztec cuisine to the research laboratory. International Microbiology, 1, 149-158. Retrieved from http://www. im.microbios.org/02june98/10\%20Ruiz\%20Herrera.pdf
Sahagún, B. (1989). General history of the things of New España (2nd ed.). Mexico: National Council for Culture and the Arts-Alliance Editorial Mexicana.

Simeón, R. (1977). Nahuatl language dictionary o Mexicana. Mexico: 21st Century: Our America.

Singleton, V. L., Orthofer, R., \& Lamuela-Raventós, R. M. (1999). Analysis of total phenols and other oxidation substrates and antioxidants by means of Folin-Ciocalteu reagent. Methods in Enzymology, 299, 152-178. http://dx.doi.org/10.1016/S0076-6879(99)99017-1.

Toit, L. J., \& Pataky, J. K. (1999a). Effects of silk maturity and pollination on infection of maize ears by Ustilago maydis. Plant Disease, 83(7), 621-626. http://dx.doi.org/10.1094/PDIS.1999.83.7.621.

Toit, L. J., \& Pataky, J. K. (1999b). Variation associated with silk channel inoculation for common smut of sweet corn. Plant Disease, 83(8), 727-732. http://dx.doi.org/10.1094/PDIS.1999.83.8.727.

Valdez-Morales, M., Barry, K., Fahey, G. C. Jr, Domínguez, J., de Mejia, E. G., Valverde, M. E., \& Paredes-López, O. (2010). Effect of maize genotype, developmental stage, and cooking process on the nutraceutical potential of huitlacoche (Ustilago maydis). Food Chemistry, 119(2), 689-697. http://dx.doi.org/10.1016/j.foodchem.2009.07.015.

Valverde, M. E., \& Paredes-López, O. (1993). Production and evaluation of some food properties of huitlacoche (Ustilago maydis). Food Biotechnology, 7(3), 207-219. http://dx.doi.org/10.1080/08905439309549858.

Valverde, M. E., Fallah Moghaddaml, P., Zavala-Gallardol, M. S., Pataky, J. K., Paredes-Lopez, O., \& Pedersen, W. L. (1993). Yield and quality of huitlacoche on sweet corn inoculated with Ustilago maydis. HortScience, 28(8), 782-785. Retrieved from http://hortsci. ashspublications.org/content/28/8/782.full.pdf

Valverde, M. E., Hernández-Pérez, T., \& Paredes-López, O. (2015). Edible mushrooms: improving human health and promoting quality life. International Journal of Microbiology, 2015(2015), ID376387.

Vanegas, P. E., Valverde, M. E., Paredes-Lopez, O., \& Pataky, J. K. (1995). Production of the edible fungus huitlacoche (Ustilago maydis): Effect of maize genotype on chemical composition. Journal of Fermentation and Bioengineering, 80(1), 104-106. http://dx.doi. org/10.1016/0922-338X(95)98187-P.

Villanueva, C. (1997). "Huitlacoche" (Ustilago maydis) as a food in Mexico. Micología Neotropical Aplicada, 10, 73-81.

Zhishen, J., Mengcheng, T., \& Jianming, W. (1999). The determination of flavonoid contents in mulberry and their scavenging effects on superoxide radicals. Food Chemistry, 64(4), 555-559. http://dx.doi. org/10.1016/S0308-8146(98)00102-2. 